\title{
Abundance and Diversity of Native Bumble Bees Associated with Agricultural Crops: The Willamette Valley Experience
}

\author{
Sujaya Rao and W. P. Stephen \\ Department of Crop and Soil Science, Oregon State University, 3017 ALS, Corvallis, OR 97331, USA \\ Correspondence should be addressed to Sujaya Rao, sujaya@oregonstate.edu
}

Received 20 August 2009; Accepted 2 December 2009

Academic Editor: James C. Nieh

Copyright (๑) 2010 S. Rao and W. P. Stephen. This is an open access article distributed under the Creative Commons Attribution License, which permits unrestricted use, distribution, and reproduction in any medium, provided the original work is properly cited.

\begin{abstract}
There are widespread concerns about declining populations of bumble bees due to conversion of native habitats to agroecosystems. Certain cropping systems, however, provide enormous foraging resources, and are beneficial for population build up of native bees, especially eusocial bees such as bumble bees. In this review, we present evidence of a flourishing bumble bee fauna in the Willamette Valley in western Oregon which we believe is sustained by cultivation of bee-pollinated crops which bloom in sequence, and in synchrony with foraging by queens and workers of a complex of bumble bee species. In support of our perspective, we describe the Oregon landscape and ascribe the large bumble bee populations to the presence of a pollen source in spring (cultivated blueberries) followed by one in summer (red clover seed crops). Based on our studies, we recommend integration into conservation approaches of multiple agroecosystems that bloom in sequence for sustaining and building bumble bee populations.
\end{abstract}

\section{Introduction}

There are widespread concerns about declines in the numbers and distribution of endemic bees [1-4]. In the Holarctic region, concerns relate, in particular, to eusocial bumble bees, Bombus spp. (Hymenoptera: Apidae), which are important pollinators of native plants and crops $[5,6]$. In Europe, Bombus populations have been closely monitored for decades, and loss of bumble bees and their nesting sites have been attributed largely to anthropogenic activities such as habitat fragmentation due to agricultural intensification and urbanization [7]. To counteract the negative effects of modern agriculture on the environment, agri-environment schemes have been implemented through which financial incentives have been provided to farmers to manage their farms for the benefit of biodiversity, the environment, or the landscape [8]. These include strategies targeted at pollinators, such as appropriate management along field margins for providing food resources and nesting sites [9]. However, densities of bumble bees have been documented to be determined not by the proportion of seminatural habitats but by the presence of rewarding mass flowering crops in agricultural landscapes [10]. Bumble bee colonies live for several months while bloom in a crop lasts for just a few weeks. Hence, one mass flowering crop alone is usually not adequate for sustaining a bumble bee colony through the year.

Here, we provide a contrary perspective to bumble bee declines while describing the abundant and diverse bumble bee fauna in the state of Oregon on the west coast of the United States. We believe that this rich fauna has been sustained by the practice of farming of bee-pollinated crops that bloom in sequence, and in synchrony with foraging by a complex of bumble bee species. In support of our opposing perspective to the pollination crisis, we describe the Oregon landscape and present results of our studies in which we estimated the diversity and abundance of native bumble bees in a spring crop and a summer crop. Based on our studies, we recommend integration into conservation approaches of multiple agroecosystems that bloom in sequence for sustaining and building bumble bee populations.

\section{The Oregon Landscape}

The state of Oregon lies north of California on the west coast of the United States. It has a land area of 25 million ha with a low population of only 3.79 million or 


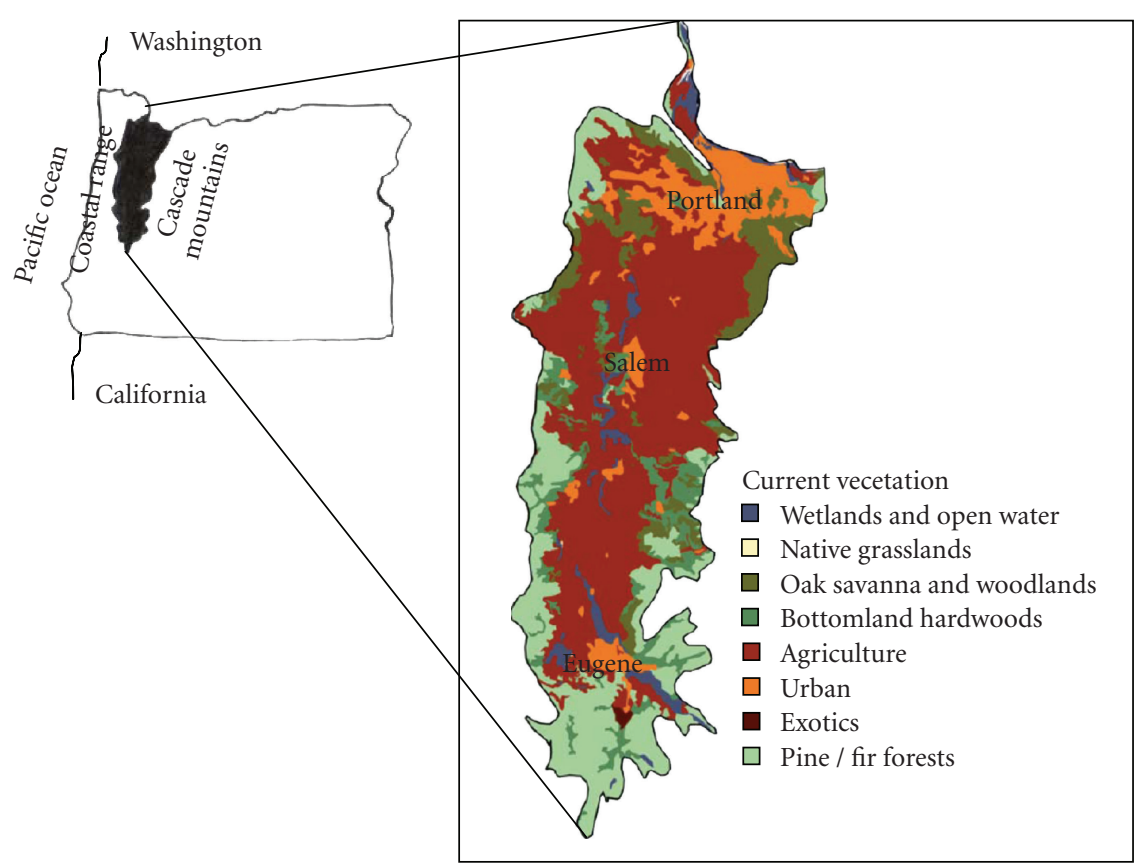

FIgURE 1: Map of the Willamette Valley in western Oregon showing agricultural, wooded, and urban landscapes (Modified from [11]).

0.15 people per ha, and $27 \%$ devoted to farming (http://www .us-places.com/Oregon/Oregon.htm). Urban development is concentrated in the three cities of Portland, Salem, and Eugene in western Oregon and, even within these cities, farm lands lie adjacent to housing developments. The vast landscapes of agricultural production are interspersed with remnant vegetation as the state was dominated by forests until recently.

The heart of the agricultural country in Oregon, and one of the most fertile agricultural areas in the U.S, is the Willamette Valley, the large valley of the Willamette River in the western part of the state (Figure 1) [11]. With the Cascade Mountains to the east and the Oregon Coast Range to the west, the valley stretches $177 \mathrm{~km}$ north to south and $97 \mathrm{~km}$ east to west. Due to its proximity to the Pacific Ocean, it receives close to $100-115 \mathrm{~cm}$ rainfall in the winter while the summer months of July and August are almost rain free. Crops grow vigorously as a result of winter rainfall, and harvest is facilitated by the dry conditions in summer. These climatic conditions have resulted in the production of over 200 crops including cereals, ornamentals, nursery crops, and bee-pollinated fruits, vegetables, and legumes raised for seed.

\section{Bumble Bees Associated with Agricultural Crops in the Willamette Valley}

Crop producers in other US states can use commercially reared Bombus impatiens Cresson for pollination. However, B. impatiens is not native to Oregon, and exotic bumble bees cannot be introduced into the state (http://www.oregon .gov/ODA/PLANT/IPPM/appr_insects.shtml). Hence, for crops serviced by bumble bees, producers in Oregon are dependent on native bumble bee populations.
Native bumble bees were first studied in depth in Oregon in the late 1950s [12]. Few follow up studies were conducted until we serendipitously discovered a highly bee-specific blue vane trap that facilitated evaluation and monitoring of native bee fauna [13]. Our recent bee census studies have documented that over 60 species belonging to 19 genera in five families are present in western Oregon [1316]. These include a rich complex of spring and summer bumble bee species whose life cycles are synchronous with the bloom periods of many crops grown in the Willamette Valley. Here we present results of our studies on bumble bee composition and abundance during bloom in two Oregon cash crops in the Willamette Valley, namely highbush blueberries (Vaccinium corymbosum L., Ericaceae) and red clover (Trifolium pratense L., Fabaceae) raised for seed. In each crop, our objectives were to estimate the diversity and abundance of bumble bees: (1) in the landscape and (2) foraging on crop bloom.

\section{Pollination and Blueberry Production in the Willamette Valley}

Blueberry is native to North America but cultivated worldwide. In Oregon, highbush blueberries are raised in the Willamette Valley. With increasing consumer awareness about the health benefits of blueberries, the area under blueberry production in Oregon doubled in the last decade from 860 ha in 1997 to 1,782 ha in 2007 [15].

Under western Oregon conditions, bloom lasts for about 4 weeks in May. Pollination during this period is critical for larger fruit, better fruit quality, and earlier ripening of berries [17-20]. In Oregon, producers typically stock high numbers of hives of the European honey bee, Apis mellifera 
TABLE 1: Bumble bee species observed foraging on bloom in commercial blueberry and red clover seed production fields in western Oregon.

\begin{tabular}{|c|c|c|}
\hline \multirow[t]{2}{*}{ Bumble bee species } & \multicolumn{2}{|c|}{$\%$ of all Bombus foragers ${ }^{1}$} \\
\hline & Blueberry bloom $^{2}$ & Red clover bloom ${ }^{3}$ \\
\hline Bombus appositus & 1.57 & 1.74 \\
\hline Bombus californicus & 3.92 & 1.87 \\
\hline Bombus griseocollis & 15.69 & 0.68 \\
\hline Bombus melanopygus & 12.55 & 0.00 \\
\hline Bombus mixtus & 8.23 & 0.31 \\
\hline Bombus nevadensis & 5.49 & 3.17 \\
\hline Bombus vosnesenskii ${ }^{4}$ & 52.55 & 92.23 \\
\hline
\end{tabular}

${ }^{1}$ Based on visual observations made while walking in the field.

${ }^{2}$ From [23].

${ }^{3}$ From [16].

${ }^{4} \mathrm{~A}$ small proportion (2-3\%) of these were likely to have been B. caliginosus which is phenotypically very similar to $B$. vosnesenskii and cannot be accurately separated from it in the field.

L. (Hymenoptera: Apidae), ranging from 2.5 to 7 hives per ha to compensate for their low efficiency in pollination of blueberries (personal observation). Honey bees do not forage at temperatures below $12.7^{\circ} \mathrm{C}[21]$, which are common during blueberry bloom in the Willamette Valley. In addition, honey bees do not buzz pollinate, the mechanism by which certain bees visiting the flowers vibrate their body to remove the pollen grains from the anthers of blueberries [22]. In contrast, bumble bees are better foragers in western Oregon as they can forage under diverse conditions from cool to hot, and even in the rain (personal observation), and they are capable of buzz pollination. However, due to the dependence on honey bees for pollination, prior to the studies described below, there was little information about bumble bees associated with blueberry bloom in the Willamette Valley.

We quantified bumble bee composition during blueberry bloom by placement of blue vane traps in a blueberry orchard in the Willamette Valley in 2006 [23]. We captured 270 bumble bees belonging to seven species, including $B$. appositus Cresson (10 individuals), B. californicus Smith (132), B. griseocollis (DeGeer) (14), B. melanopygus Nylander (39), B. mixtus Cresson (19), B. nevadensis Cresson (17), and B. vosnesenskii Radoszkowski (39) [23]. The following year, the study was repeated at 5 other orchards which provided insights on distribution of each species [15]. Bombus californicus, B. mixtus, and B. vosnesenskii were collected at all five sites, while B. melanopygus was collected at four, and B. appositus and B. nevadensis were trapped at two sites. In 2007, B. griseocollis was not collected at any site probably because our sampling study ended before emergence of queens during that year.

The presence and abundance of six to seven species of bumble bees during bloom in a spring crop are quite remarkable. However, presence of a species in the trap does not necessarily indicate that it forages on the surrounding crop. Hence, in 2006, to quantify the composition of bumble bees foraging on blueberry flowers, we made visual observations during 2-minute periods while walking along rows of blueberry bushes [23]. We recorded 255 bumble bees from 127 sets of counts ( $=1$ bumble bee/min) including $B$. appositus (4 individuals), B. californicus (10), B. griseocollis (40), B. melanopygus (32), B. mixtus (21), B. nevadensis (14), and $B$. vosnesenskii (134). Thus, the 7 bumble bee species captured in traps in the same year were also observed foraging on bloom, though in different proportions. While the seven species varied in the proportion of foragers on bloom (Table 1), all are likely to contribute to blueberry pollination as none was observed robbing nectar by chewing holes in blossoms at the base of the flowers, behavior exhibited by certain bumble bee species in other regions [24]. Of the 255 specimens observed, $208(81.6 \%)$ were queens and 47 $(18.4 \%)$ were workers indicating that the pollinating force was composed primarily of newly emergent queens (Figures 2 and 3 ). This is beneficial for blueberry pollination as the efficiency of bumble bee queens as blueberry pollinators is reported to be higher than that of bumble bee workers [25].

A comparison of the bumble bee fauna captured in the blue vane traps in our study with other trapping studies is a challenge due to differences in sampling protocols. However, bumble bee abundance in Willamette Valley blueberries appears to be greater compared to other regions based on estimates of foragers reported in other studies. As mentioned earlier, in our study we recorded an average of 1 bumble bee/min foraging on blueberry bloom [23]. In contrast, MacKenzie and Eickwort [26] estimated 0.04 bumble bees/min foraging on highbush blueberries in upstate New York, while in blueberry fields in the Fraser Valley in British Columbia, the mean number of native bees, including both bumble bees and solitary bees, recorded by MacKenzie and Winston [27] was $33 / \mathrm{h}(=0.55 / \mathrm{min})$. Bumble bee diversity in foragers is also quite variable. We observed seven species in our study while in a study conducted in Michigan [28] only one bumble bee species, Bombus bimaculatus Cresson, was observed foraging on blueberry bloom.

We also assessed bumble bee activity in one blueberry field. Based on visual observations and the presence of 2,720 bushes/ha, we estimated an average of 0.055 bumble bees/bush/min (=150 bumble bees/ha/min). The average time spent by one bumble bee foraging on one flower was 4 seconds ( $=15$ flowers/min) including the time spent moving from one flower to another. Based on these estimates, 135,000 flowers/ha/hour/bee were potentially visited, or over 11.3 million over a 14-day period assuming that the bumble bee population remained relatively constant for six hours (10:00 am and 4:00 pm) each day. The estimate is conservative as blueberry bloom extends beyond two weeks in the Willamette Valley, and bumble bees are active in blueberry fields up to 10 hours a day during that period (personal observations). With the abundance and long duration of their foraging activity observed in the current study, we believe that bumble bees could have contributed considerably to the high yield ( $>15$ ton/ha) recorded by the producer (personal communication).

Honey bees are not considered to be effective pollinators of blueberries, but in the Willamette Valley, given the presence of 2.5 to 7 hives/ha in the field, they likely contributed 


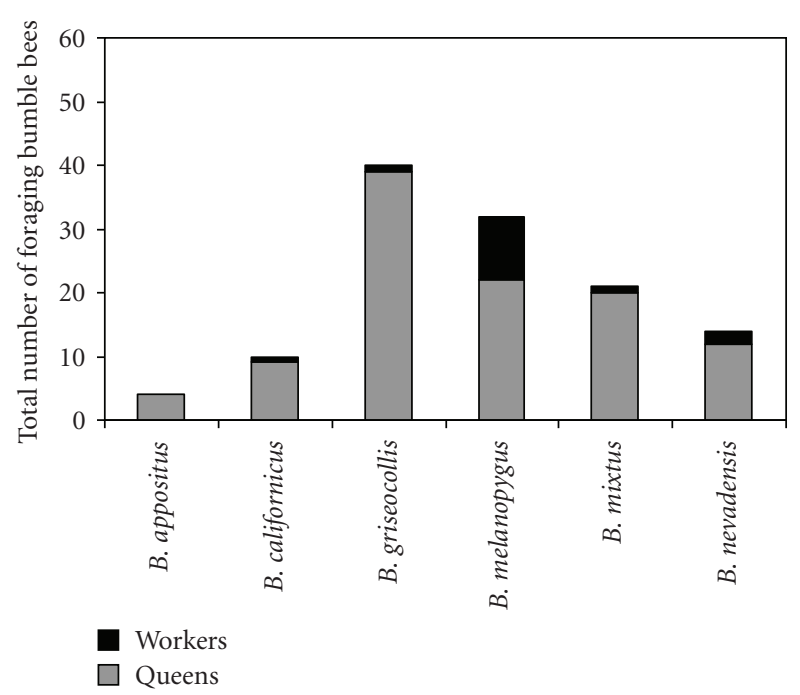

(a)

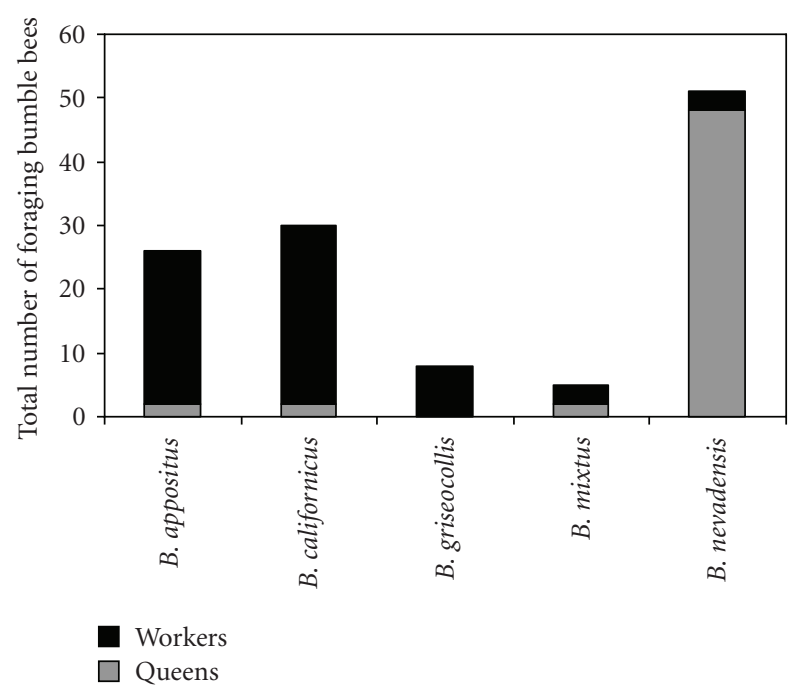

(b)

Figure 2: Comparison of the numbers of queens and workers of bumble bee species (excluding B. vosnesenskii which is included in Figure 3) observed foraging on bloom. (a) Blueberries ( $n=127$ counts). (b) Red Clover ( $n=187$ counts).

to some extent. Similarly, other native bees could also have played a role. In our studies conducted between 2005 and 2009, we have captured several hundred native solitary bees belonging to 23 species in ten genera in five families in the blue vane traps placed adjacent to blueberry fields in spring (Table 2). However, we rarely encountered any non-Bombus native bee foraging on bloom during our 2-minute counts (personal observation). In a study in British Columbia [27], while solitary bees were observed on blueberry bloom, there were ten times more bumble bees. Diversity of solitary bees was high in another study conducted in British Columbia [29], but blueberry mass was observed to be related not to abundance of solitary bees or of honey bees, but to that of bumble bees. Still, further research is needed for determining

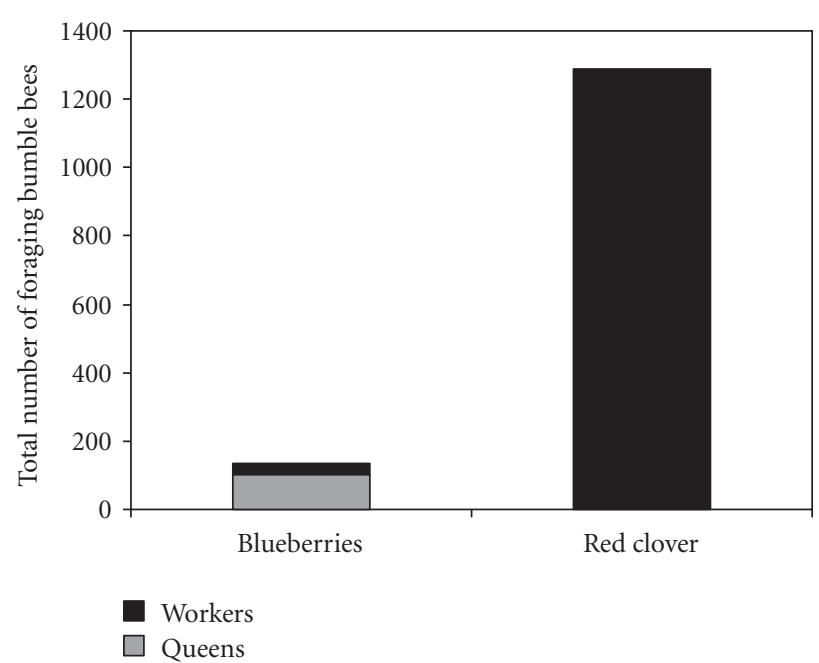

Figure 3: Comparison of the numbers of queens and workers of $B$. vosnesenskii observed foraging on bloom $(n=127$ counts $)$ and red clover ( $n=187$ counts).

the impact of solitary bees in blueberry pollination in the Willamette Valley.

\section{Pollination and Red Clover Seed Production in the Willamette Valley}

Red clover is grown worldwide in temperate regions as a forage legume, and as a rotation crop for soil improvement [30]. The Willamette Valley is a key region for red clover seed production in the US due to the favorable climatic conditions. The high rainfall during winter enables the production of red clover with minimal irrigation, while the relatively dry periods in summer facilitate harvest with little risk of rain damage (http://www.oregonclover.org/seedproduction.html). As a result, over 4,300 ha are under red clover seed production in this area [31].

The critical factor for seed production in red clover is pollination [32-34]. Red clover blooms over six weeks in the months of July and August in Oregon. The florets on each seed head open over six to eight days but due to rapid decrease in fertility, the florets must be pollinated within two to four days after opening [35]. Hollowell and Tysdal [36] indicated that 875 million florets are present in a hectare of red clover. This highlights the need for an abundance of pollinators for achieving high yield in red clover seed crops.

While bees are recognized as the primary pollinators of red clover, there has been considerable disagreement over the value of various species [37, 38]. Darwin's claim that bumble bees alone affected red clover yield [39] was disputed by Meehan [40] but dramatic evidence of their impact was provided by the introduction of bumble bees to New Zealand as this resulted in an enormous increase in seed production [37]. Since the honey bee was already present in the country, this appeared to confirm that honey bees were of limited value to red clover. Subsequent studies documented that while honey bees do pollinate this crop, 
TABLE 2: Endemic bees captured and observed as foragers during bloom in blueberry and red clover seed crops in the Willamette Valley in studies conducted between 2005 and 2009.

\begin{tabular}{|c|c|c|c|}
\hline Family & Species & Blueberry ${ }^{1,2}$ & Red clover ${ }^{1,3}$ \\
\hline \multirow[t]{2}{*}{ Colletidae } & Hylaeus calvus (Metz) & $\sqrt{ }$ & $\sqrt{ }$ \\
\hline & Hylaeus rudbeckiae Cockerell and Casad & $\sqrt{ }$ & $\sqrt{ }$ \\
\hline \multirow[t]{14}{*}{ Halictidae } & Agapostemon texanus Cresson & $\sqrt{ }$ & $\sqrt{ }$ \\
\hline & Agapostemon virescens (Fabricius) & $\sqrt{ }$ & $\sqrt{ }$ \\
\hline & Halictus confusus Smith & $\sqrt{ }$ & \\
\hline & Halictus farinosus Smith & $\sqrt{ }$ & $\sqrt{ }$ \\
\hline & Halictus ligatus Say & $\sqrt{ }$ & $\sqrt{ }$ \\
\hline & Halictus rubicundus (Christ) & $\sqrt{ }$ & $\sqrt{ }$ \\
\hline & Halictus tripartitus Cockerell & $\sqrt{ }$ & $\sqrt{ }$ \\
\hline & Lasioglossum mellipes (Crawford) & $\sqrt{ }$ & $\sqrt{ }$ \\
\hline & Lasioglossum olympiae (Cockerell) & $\sqrt{ }$ & $\sqrt{ }$ \\
\hline & Lasioglossum pacificum (Cockerell) & $\sqrt{ }$ & $\sqrt{ }$ \\
\hline & Lasioglossum sisymbrii (Cockerell) & $\sqrt{ }$ & \\
\hline & Lasioglossum titusi (Crawford) & $\sqrt{ }$ & \\
\hline & Lasioglossum trizonatum (Cresson) & $\sqrt{ }$ & $\sqrt{ }$ \\
\hline & Sphecodes sp. & $\sqrt{ }$ & $\sqrt{ }$ \\
\hline Andrenidae & Andrena sp. & $\sqrt{ }$ & $\sqrt{ }$ \\
\hline \multirow[t]{6}{*}{ Meghachilidae } & Anthidium sp. & $\sqrt{ }$ & \\
\hline & Heriades sp. & & $\sqrt{ }$ \\
\hline & Megachile brevis Say & & $\sqrt{ }$ \\
\hline & Megachile perihirta Cockerell & & $\sqrt{ }$ \\
\hline & Osmia lignaria Say & $\sqrt{ }$ & $\sqrt{ }$ \\
\hline & Osmia sp. & $\sqrt{ }(2)$ & $\sqrt{ }(5)$ \\
\hline \multirow[t]{22}{*}{ Apidae } & Anthophora bomboides stanfordiana Cockerell & & $\sqrt{ }$ \\
\hline & Anthophora urbana Cresson & & $\sqrt{ }$ \\
\hline & Bombus appositus Cresson & $\sqrt{ }$ & $\sqrt{ }$ \\
\hline & Bombus bifarius nearcticus Handlirsch & $\sqrt{ }$ & \\
\hline & Bombus californicus Smith & $\sqrt{ }$ & $\sqrt{ }$ \\
\hline & Bombus caliginosus (Frison) & & $\sqrt{ }$ \\
\hline & Bombus griseocollis (DeGeer) & $\sqrt{ }$ & $\sqrt{ }$ \\
\hline & Bombus melanopygus Nylander & $\sqrt{ }$ & $\sqrt{ }$ \\
\hline & Bombus mixtus Cresson & $\sqrt{ }$ & $\sqrt{ }$ \\
\hline & Bombus nevadensis Cresson & $\sqrt{ }$ & $\sqrt{ }$ \\
\hline & Bombus occidentalis Greene & & $\sqrt{ }$ \\
\hline & Bombus sitkensis Nylander & & $\sqrt{ }$ \\
\hline & Bombus vosnesenskii Radoszkowski & $\sqrt{ }$ & $\sqrt{ }$ \\
\hline & Ceratina acantha Provancher & $\sqrt{ }$ & $\sqrt{ }$ \\
\hline & Ceratina micheneri Daly & & $\sqrt{ }$ \\
\hline & Ceratina nanula Cockerell & & $\sqrt{ }$ \\
\hline & Melissodes agilis Cresson & & $\sqrt{ }$ \\
\hline & Melissodes bimatris LaBerge & & $\sqrt{ }$ \\
\hline & Melissodes robustior Cockerell & & $\sqrt{ }$ \\
\hline & Psythirus sp. & & $\sqrt{ }$ \\
\hline & Synhalonia sp. & $\sqrt{ }$ & $\sqrt{ }$ \\
\hline & Triepeolus sp. & & $\sqrt{ }(2)$ \\
\hline
\end{tabular}

\footnotetext{
${ }^{1}$ Numbers in parenthesis refer to number of species.

${ }^{2}$ From $[15,23]$, and unpublished data.

${ }^{3}$ From [16], and unpublished data.
} 
their efficacy depends on the amount of competing foraging resources in the vicinity $[32,41]$. In Oregon, red clover seed producers typically stock 2.5 to 5 hives per ha for pollination but the recent high costs of honey bee rentals have led producers to question the value of honey bee hive rentals (personal communication). However, they were unwilling to take the risk of depending on native bumble bees and other pollinators, as prior to the studies outlined below, there was little information about bumble bees present during red clover bloom.

We conducted a monitoring study with blue vane traps in three red clover seed production fields in 2007 to estimate the bumble bee composition in the area during bloom [16]. In all, 1,227 bumble bees including six of the seven species trapped in blueberries were also trapped in red clover. We collected B. appositus (15 individuals), B. californicus (19), B. griseocollis (26), B. mixtus (7), B. nevadensis (28), and B. vosnesenskii $(1,132)$. Each species was collected at all three sites. While B. melanopygus was not collected in traps at any site in 2007, we recorded its presence in traps in red clover seed fields in other years [16]. It is an early spring emerging species, and colonies typically die out by the time red clover blooms.

As in the case of blueberries, we studied bumble bee foraging on red clover by recording the numbers of each species observed while walking through the field. The same six bumble bee species that were observed in the traps were also observed foraging on bloom (Figures 2 and 3) [16]. In 187 visual counts, 1-2 min each, we noted the presence of 1,609 bees (queens, workers, and males). There was a greater proportion of workers compared to queens in all species except B. nevadensis (Figures 2 and 3 ). The species observed included B. appositus (28 individuals), B. californicus (30), B. griseocollis (11), B. mixtus (5), B. nevadensis (51), and B. vosnesenskii $(1,484)$. Proportions of bumble bee species differed from those recorded in blueberries but $B$. vosnesenskii was dominant in both cropping systems (Table 1). Interestingly, of these species, only $B$. griseocollis has been reported elsewhere as a pollinator of red clover [42-44].

Overall, we recorded an average of 6.2 bumble bees per minute across the six weeks of red clover bloom. Early bloom abundance of 0-4 bumble bees/min dramatically increased during peak bloom to $15-30$ bees/min. In comparison, in a study by Morrison conducted in Quebec, 1,901 bumble bees were observed visiting red clover during 68 observations, 20 minutes each (=1.4 bumble bees/min) [43].

A cage study conducted by us demonstrated that $B$. vosnesenskii is an efficient pollinator of red clover [16]. Mean seed yield from the B. vosnesenskii cages was $661 \mathrm{~kg} / \mathrm{ha}$ (range $=623$ to $685 \mathrm{~kg} / \mathrm{ha}$ ), and variances in seed yield and seed set were low which is indicative of consistency in performance. The B. vosnesenskii cage yield was slightly higher than the average yield in Oregon $(600 \mathrm{~kg} / \mathrm{ha})$ which in itself was almost $40 \%$ higher than the US average ( $430 \mathrm{~kg} / \mathrm{ha})$ in the same year [31]. Given the high proportion (>90\%) of $B$. vosnesenskii observed foraging on red clover florets during visual observations and in the blue vane traps, we believe that it is a key contributor to Oregon becoming the second largest red clover seed producer in the US [31].
For a deeper understanding of its foraging behavior, we are currently characterizing pollen loads on $B$. vosnesenskii workers returning to colonies placed adjacent to red clover fields. We are also using genetic markers to determine nest composition and foraging range of this dominant bumble bee species in the Willamette Valley.

The role of other native bees in red clover pollination in the Willamette Valley is not known. We have caught several hundred solitary bees belonging to 35 species in 15 genera in five families during bloom (Table 2). However, as in the case of blueberries, we rarely encountered non-Bombus bees foraging on bloom during our 2-minute counts. According to Plath [37], while occasionally a solitary bee will forage on red clover, the crop would probably set little seed if its pollination depended on other insects besides bumble bees.

In Oregon, while honey bee hives are rented for red clover seed crop pollination, worker abundance is high only during early bloom in July [16]. Pollen traps placed in hives documented that midway through bloom the workers switch to foraging elsewhere (personal observation). Honey bee foraging away from red clover fields coincided with high numbers of bumble bee foragers in red clover. This suggests that the low number of bumble bees in early-mid July could be the result of competition with honey bees. Peterson et al. [41] reported that bumble bees tended to be more abundant in fields located $>1.6 \mathrm{~km}$ away from apiaries (honey bee colonies). Also, earlier studies have documented negative impacts on factors such as reproductive success [45] and size of workers [46] of bumble bees in areas of high honey bee density. It is possible that foraging behavior could also be affected by the presence of honey bees, and hence bumble bee abundance may be even greater if producers do not stock honey bee hives. We are currently comparing bumble bee abundance and red clover pollination in the presence and absence of honey bee hive rentals.

\section{Willamette Valley Model for Bumble Bee Abundance}

It is believed that pollinator populations cannot be maintained by short-flowering agricultural crops alone because of the need of a continuous supply of nectar and pollen [47]. However, wild habitats do not necessarily satisfy these needs either. In contrast, cropping systems that flower in sequence can facilitate sustainability and build up of native bees especially eusocial bees. For maximum production of workers, initial vigor of spring queens is important [44] which can be achieved through provision of a spring-blooming beepollinated crop. Cultivated legumes are considered to be important in maintaining native bumble bee fauna [44], and if such crops bloom towards the end of summer, build up of bumble bees will be facilitated during the period when high numbers of reproductives are produced prior to hibernation of queens at the end of the year. We believe that the abundance of a complex of seven bumble bee species in the Willamette Valley is sustained due to the large areas under production of blueberries which provide large quantities of food resources in synchrony with queen emergence thereby 
facilitating nest foundation, and of red clover seed crops which provide resources for drones and hibernating queens. The presence of six to seven bumble bee species has been reported in other regions in the US both in agricultural and native habitats $[26,29,44,48]$ but abundances are lower than what we observed. Of the species present in the Willamette Valley, while Bombus vosnesenskii was the most abundant bumble bee in both blueberries and red clover, queens and/or workers of all the remaining bumble bee species carried pollen loads in both blueberries and red clover, and thus they all contribute to some extent to both blueberry and red clover pollinations. In particular, queens of B. nevadensis $>20 \mathrm{~mm}$ long and their large sized workers observed with large loads of pollen are likely to make a valuable contribution to pollination.

Besides the seven species that are flourishing, on occasion we have trapped the bumble bee species B. bifarius nearcticus Handlirsch and B. sitkensis Nylander in agricultural landscapes in the Willamette Valley (Table 1). In addition, a small proportion (2-3\%) of the B. vosnesenskii observed in the studies were likely to have been $B$. caliginosus (Frison) which is phenotypically very similar to it. In the past, one more species, B. occidentalis Greene, was abundant in the Willamette Valley and in other parts of the Pacific Northwest [12]. However, since the late 1990s, it has all but disappeared from coastal and coastal valleys of its range presumably because of its vulnerability to introduced pathogens [4951]. In the period leading up to its decline, queens of B. occidentalis collected from the west coast were sent to rearing facilities in the Midwest and Europe where they were raised commercially along with other bumble bee species. It is speculated that colonies returned to the west coast for pollination of greenhouse crops were infected with Nosema bombi and/or other pathogens to which B. occidentalis appeared to be highly susceptible [52]. The spillover effects from these commercial colonies to wild populations likely resulted in local extinction of $B$. occidentalis $[53,54]$. We collected six individuals of $B$. occidentalis from clover fields in 2006 and 2007 [55], which suggests a possible recovery of the species in the area. The ban on introduction of exotic commercial bumble bees mentioned above should reduce further risk to the rich bumble bee fauna in Oregon.

The agricultural landscapes in the Willamette Valley also support a rich diversity of other native bees besides 11 bumble bee species. We trapped 39 species of solitary native bees belonging to 16 genera in five families in blueberry and red clover fields (Table 2). We rarely detected their presence on bloom but they could have escaped detection as we focused on bumble bees in our studies. The impact of Willamette Valley cropping systems on sustenance of diverse solitary bees, and the contribution of these bees to crop pollination, warrants investigation.

Besides the abundance of food resources provided by blueberry and red clover crops, other factors such as production practices also facilitate build up of bumble bees and other native bees in the Willamette Valley. While each crop is routinely subjected to pesticide sprays, there are few devastating pests perhaps due to the diversified nature of the agricultural landscapes. Except for one blueberry orchard where organic practices were adopted, all other blueberry and all red clover seed fields in our studies were cultivated using herbicides, fungicides, and insecticides. However, pesticide applications were avoided during bloom or implemented at night to minimize negative impacts on honey bees, thus indirectly benefitting bumble bees too. Voles cause significant damage in agricultural crops in the Willamette Valley, and rodenticides are used for their management. This has been of benefit to bumble bees as empty rodent nests serve as nesting sites in close proximity to foraging resources in the crop. Remnant vegetation between agricultural fields may also be providing nesting habitats and overwintering sites for queens.

Urban developments adjacent to agricultural fields in the Willamette Valley also provide both foraging resources and nesting sites for bumble bees. Climatic conditions support growth of a great diversity of native and exotic annual and perennial flowering plants in gardens, and bumble bees have been observed to nest frequently in various urban locations. Due to the ban on commercial bumble bee colony introduction into Oregon, for our cage study, we sought colonies by placement of a request in the local newspaper in 2007 [16]. Since then we have received numerous calls from homeowners, and have noted the presence of nests of B. griseocollis, B. melanopygus, B. mixtus, and B. vosnesenskii in bird boxes, compost heaps, bags of potting soil, and insulation in sheds, homes, pump houses, and a diversity of other locations.

The current western Oregon landscape can serve as a model for bumble bee conservation as it provides both nesting sites and an abundance of foraging resources, the two critical needs of bumble bees. Based on our experiences, we recommend integration of multiple agroecosystems that bloom in sequence for conservation and build up of bumble bee populations. However, crops raised by farmers are dependent on markets, and hence even in the Willamette Valley, it may not always be possible to provide a sequence in forage resources in agricultural landscapes through cropping systems. In such situations, conservation efforts are essential. Irrespective of the approach adopted globally in agri-environment schemes or other pollinator initiatives, it is critical that attention is directed not just to providing foraging resources but to ensuring that there is a continuum in the presence of the food resources. Hence, in areas where a sequence in bloom in bee-pollinated cropping systems is not an option, rather than just recommending planting of hedgerows or providing lists of bee-friendly plants, researchers should develop and implement plans that include planting of a series of plants that bloom in sequence.

\section{Acknowledgments}

The authors thank blueberry and red clover seed producers for permitting them to conduct the studies in their fields. Support for the studies was provided by the Oregon Blueberry Commission, Oregon Clover Commission, and WSARE (Western Regional Agriculture, Research and Education). 


\section{References}

[1] G. Allen-Wardell, P. Bernhardt, R. Bitner, et al., "The potential consequences of pollinator declines on the conservation of biodiversity and stability of food crop yields," Conservation Biology, vol. 12, no. 1, pp. 8-17, 1998.

[2] C. A. Kearns, D. W. Inouye, and N. M. Waser, "Endangered mutualisms: the conservation of plant-pollinator interactions," Annual Review of Ecology and Systematics, vol. 29, pp. 83-112, 1998

[3] C. Kremen, N. M. Williams, and R. W. Thorp, "Crop pollination from native bees at risk from agricultural intensification," Proceedings of the National Academy of Sciences of the United States of America, vol. 99, no. 26, pp. 16812-16816, 2002.

[4] J. C. Biesmeijer, S. P. M. Roberts, M. Reemer, et al., "Parallel declines in pollinators and insect-pollinated plants in Britain and the Netherlands," Science, vol. 313, no. 5785, pp. 351-354, 2006.

[5] S. A. Corbet, I. H. Williams, and J. L. Osborne, "Bees and the pollination of crops and flowers in the European Community," Bee World, vol. 72, pp. 47-59, 1991.

[6] S. L. Buchmann and G. P. Nabhan, The Forgotten Pollinators, Island Press, Washington, DC, USA, 1996.

[7] D. Goulson, G. C. Lye, and B. Darvill, "Decline and conservation of bumble bees," Annual Review of Entomology, vol. 53, pp. 191-208, 2008.

[8] D. Kleijn, F. Berendse, R. Smit, and N. Gilissen, "Agrienvironment schemes do not effectively protect biodiversity in Dutch agricultural landscapes," Nature, vol. 413, no. 6857, pp. 723-725, 2001.

[9] C. Carvell, W. R. Meek, R. F. Pywell, D. Goulson, and M. Nowakowski, "Comparing the efficacy of agri-environment schemes to enhance bumble bee abundance and diversity on arable field margins," Journal of Applied Ecology, vol. 44, no. 1, pp. 29-40, 2007.

[10] C. Westphal, I. Steffan-Dewenter, and T. Tscharntke, "Mass flowering oilseed rape improves early colony growth but not sexual reproduction of bumblebees," Journal of Applied Ecology, vol. 46, no. 1, pp. 187-193, 2009.

[11] P. Wiley, No Place for Nature: The Limits of Oregon's Land Use Program in Protecting Fish and Wildlife Habitat in the Willamette Valley, Defenders of Wildlife, Washington, DC, USA, 2003.

[12] W. P. Stephen, Bumble Bees of Western America (Hymenoptera: Apoidea), Oregon State University Technical Bulletin, Oregon State University, Corvallis, Ore, USA, 1957.

[13] W. P. Stephen and S. Rao, "Unscented color traps for nonApis bees (Hymenoptera: Apiformes)," Journal of the Kansas Entomological Society, vol. 78, no. 4, pp. 373-380, 2005.

[14] W. P. Stephen and S. Rao, "Sampling native bees in proximity to a highly competitive food resource," Journal of the Kansas Entomological Society, vol. 80, pp. 369-376, 2007.

[15] S. Rao, W. P. Stephen, and L. White, "Native bee pollinator diversity in Oregon blueberries," Acta Horticulturae, vol. 810, pp. 539-548, 2009.

[16] S. Rao and W. P. Stephen, "Bumble bee pollinators in red clover seed production," Crop Science, vol. 49, no. 6, pp. 22072214, 2009.

[17] L. E. Aalders and I. V. Hall, "Pollen incompatibility and fruit set in lowbush blueberry," Canadian Journal of Genetics and Cytology, vol. 3, pp. 300-307, 1961.

[18] G. W. Eaton, "The relationship between seed number and berry weight in open-pollinated highbush blueberries," HortScience, vol. 2, pp. 14-15, 1967.
[19] L. P. Jackson, L. E. Aalders, and I. V. Hall, "Berry size and seed number in commercial lowbush blueberry fields of Nova Scotia," Le Naturaliste Canadien, vol. 99, pp. 615-619, 1972.

[20] M. H. Dogterom, M. L. Winston, and A. Mukai, "Effect of pollen load size and source (self, outcross) on seed and fruit production in highbush blueberry cv. 'Bluecrop' (Vaccinium corymbosum; Ericaceae)," American Journal of Botany, vol. 87, no. 11, pp. 1584-1591, 2000.

[21] M. Burgett, G. C. Fisher, D. Mayer, and C. A. Johansen, Evaluating Honey Bee Colonies for Pollination: A Guide for Growers and Beekeepers, Oregon State University Extension Service PNW 245, Oregon State University, Corvallis, Ore, USA, 1985.

[22] S. L. Buchmann, "Buzz pollination in angiosperms," in Handbook of Experimental Pollination Biology, C. E. Jones and R. J. Little, Eds., pp. 73-113, Van Nostrand Reinhold, New York, NY, USA, 1983.

[23] W. P. Stephen, S. Rao, and L. White, "Abundance, diversity and foraging contribution of bumble bees to blueberry production in western Oregon," Acta Horticulturae, vol. 810, pp. 557-562, 2009.

[24] M. L. Winston and L. H. Graf, "Native bee pollinators of berry crops in the Fraser Valley of British Columbia," Journal of the Entomological Society of British Columbia, vol. 79, pp. 14-19, 1982.

[25] S. K. Javorek, K. E. MacKenzie, and S. P. Vander Kloet, “Comparative pollination effectiveness among bees (Hymenoptera: Apoidea) on lowbush blueberry (Ericaceae: Vaccinium angusifolium)," Annals of the Entomological Society of America, vol. 95, no. 3, pp. 345-351, 2002.

[26] K. E. MacKenzie and G. C. Eickwort, "Diversity and abundance of bees (Hymenoptera: Apoidea) foraging on highbush blueberry (Vaccinium corymbosum L.) in central New York," Journal of the Kansas Entomological Society, vol. 69, no. 4, pp. 185-194, 1996.

[27] K. E. MacKenzie and M. L. Winston, "Diversity and abundance of native bee pollinators on berry crops and natural vegetation in the lower Fraser Valley, British Columbia," Canadian Entomologist, vol. 116, no. 7, pp. 965-974, 1984.

[28] J. K. Tuell, J. S. Ascher, and R. Isaacs, "Wild bees (Hymenoptera: Apoidea: Anthophila) of the Michigan Highbush blueberry agroecosystem," Annals of the Entomological Society of America, vol. 102, no. 2, pp. 275-287, 2009.

[29] C. M. Ratti, H. A. Higo, T. L. Griswold, and M. L. Winston, "Bumble bees influence berry size in commercial Vaccinium spp. cultivation in British Columbia," Canadian Entomologist, vol. 140, no. 3, pp. 348-363, 2008.

[30] N. L. Taylor and K. H. Quesenberry, Red Clover Science, Kluwer Academic Publishers, Norwell, Mass, USA, 1996.

[31] United States Department of Agriculture, National Agricultural Statistics Service, 2007 Census of Agriculture. United States-Summary and State Data, vol. 1 of Geographic Area Series, Part 51, United States Department of Agriculture, Washington, DC, USA, 2009.

[32] J. H. Westgate and H. S. Coe, Red Clover Seed Production: Pollination Studies, vol. 289 of Bulletin of the United States Department of Agriculture, 1915.

[33] R. D. Williams, Studies Concerning the Pollination, Fertilization, and Breeding of Red Clover, vol. 4 of Welsh Plant Breeding Station Bulletin Series H, 1925.

[34] R. D. Williams, Some of the Factors Influencing Yield and Quality of Red Clover Seeds, vol. 11 of Welsh Plant Breeding Station Bulletin Series H, 1930. 
[35] J. B. Free, "The ability of bumblebees and honeybees to pollinate red clover," Journal of Applied Ecology, vol. 2, pp. 289294, 1965.

[36] E. A. Hollowell and H. M. Tysdal, "The need for seed is urgent," in Grass: The Yearbook of Agriculture, A. Stefferud, Ed., pp. 341-346, United States Department of Agriculture, Washington, DC, USA, 1948.

[37] E. Plath, "The role of bumblebees in the pollination of certain cultivated plants," American Naturalist, vol. 59, pp. 441-451, 1925.

[38] G. E. Bohart, "Pollination of alfalfa and red clover," Annual Review of Entomology, vol. 2, pp. 355-380, 1957.

[39] C. Darwin, On the Origin of Species by Means of Natural Selection, John Murrray, London, UK, 1859.

[40] T. Meehan, "Mr. Darwin on the fertilization of flowers," Pennsylvania Monthly, vol. 8, pp. 463-471, 1876.

[41] G. Peterson, B. Furgala, and F. G. Holdaway, "Pollination of red clover in Minnesota," Journal of Economic Entomology, vol. 53, pp. 546-550, 1960.

[42] L. H. Pammel and C. M. King, "Pollination of clover," Proceedings of the Iowa Academy of Sciences, vol. 18, pp. 35-45, 1911.

[43] F. O. Morrison, "Observations on the number and species of bumble bees visiting red clover," in Proceedings of the 73rd Annual Report of the Entomological Society of Ontario, pp. 1620, 1942.

[44] J. T. Medler, "Bumblebee ecology in relation to the pollination of alfalfa and red clover," Insectes Sociaux, vol. 4, no. 3, pp. 245252, 1957.

[45] D. Thomson, "Competitive interactions between the invasive European honey bee and native bumble bees," Ecology, vol. 85, no. 2, pp. 458-470, 2004.

[46] D. Goulson and K. R. Sparrow, "Evidence for competition between honeybees and bumblebees; effects on bumblebee worker size," Journal of Insect Conservation, vol. 13, no. 2, pp. 177-181, 2009.

[47] A. Holzschuh, I. Steffan-Dewenter, D. Kleijn, and T. Tscharntke, "Diversity of flower-visiting bees in cereal fields: effects of farming system, landscape composition and regional context," Journal of Applied Ecology, vol. 44, no. 1, pp. 41-49, 2007.

[48] S. E. Elliott, "Subalpine bumble bee foraging distances and densities in relation to flower availability," Environmental Entomology, vol. 38, no. 3, pp. 748-756, 2009.

[49] R. W. Thorp, "Bumble bees (Hymenoptera:Apidae): commercial use and environmental concerns," in For Nonnative Crops, Whence Pollinators of the Future, K. Strickler and J. H. Cane, Eds., Thomas Say Publications in Entomology: Proceedings, pp. 21-40, Entomological Society of America, Lanham, Md, USA, 2003.

[50] R. W. Thorp and M. D. Shepherd, "Species profile: subgenus Bombus," in Red List of Pollinator Insects of North America, M. D. Shepherd, M. Vaughan, and S. H. Black, Eds., Xerces Society for Invertebrate Conservation, Portland, Ore, USA, 2005, CDROM Version 1.

[51] Committee on the Status of Pollinators in North America, Status of Pollinators in North America, National Academies Press, Washington, DC, USA, 2007.

[52] H. H. W. Velthuis and A. van Doorn, "A century of advances in bumblebee domestication and the economic and environmental aspects of its commercialization for pollination," Apidologie, vol. 37, no. 4, pp. 421-451, 2006.
[53] R. Whittington and M. L. Winston, "Effects of Nosema bombi and its treatment fumagillin on bumble bee (Bombus occidentalis) colonies," Journal of Invertebrate Pathology, vol. 84, no. 1, pp. 54-58, 2003.

[54] M. C. Otterstatter and J. D. Thomson, "Does pathogen spillover from commercially reared bumble bees threaten wild pollinators?” PLoS ONE, vol. 3, no. 7, article e2771, 2008.

[55] S. Rao and W. P. Stephen, "Bombus (Bombus) occidentalis (Hymenoptera: Apiformes): in decline or recovery?" PanPacific Entomologist, vol. 83, no. 4, pp. 360-362, 2007. 

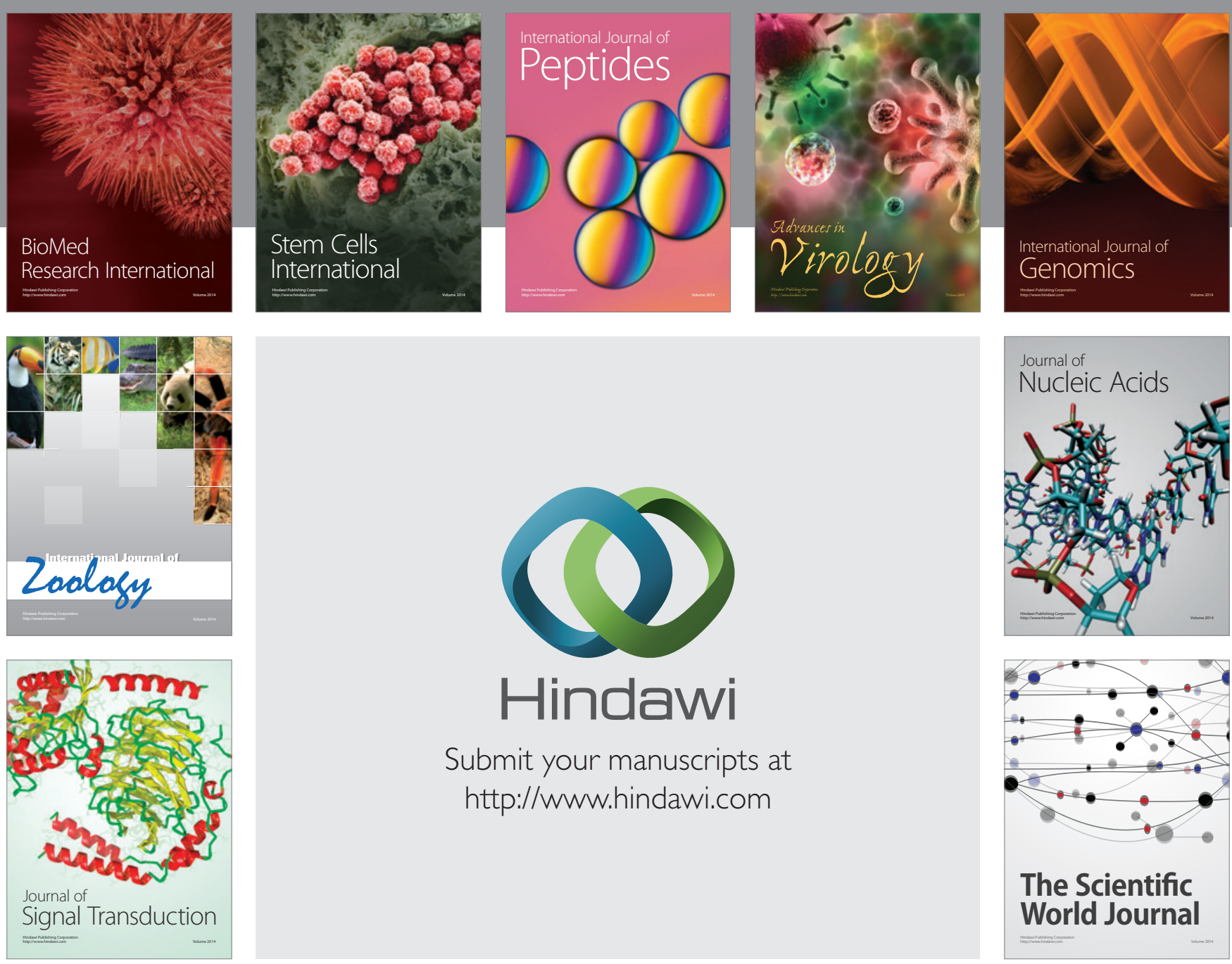

Submit your manuscripts at

http://www.hindawi.com
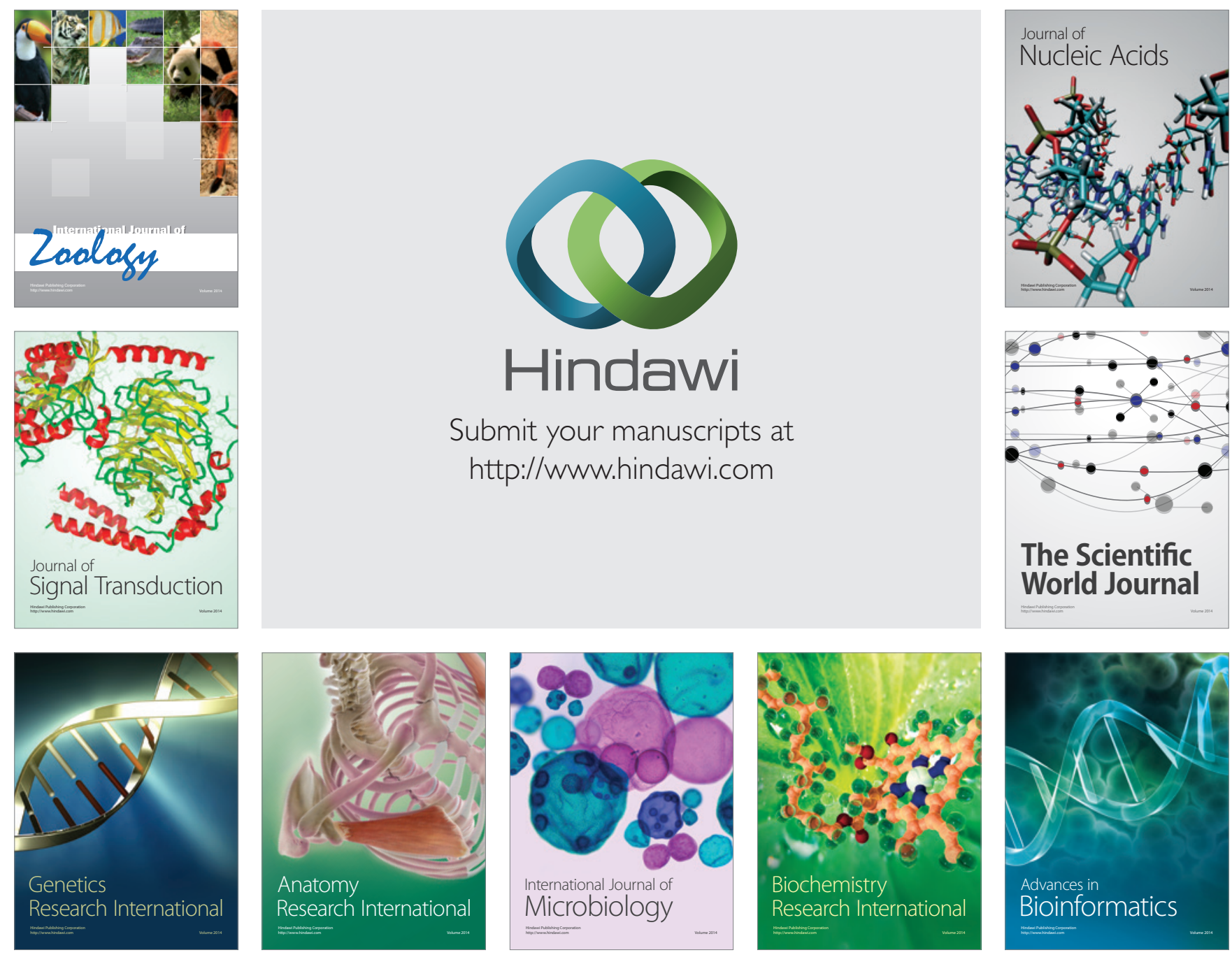

The Scientific World Journal
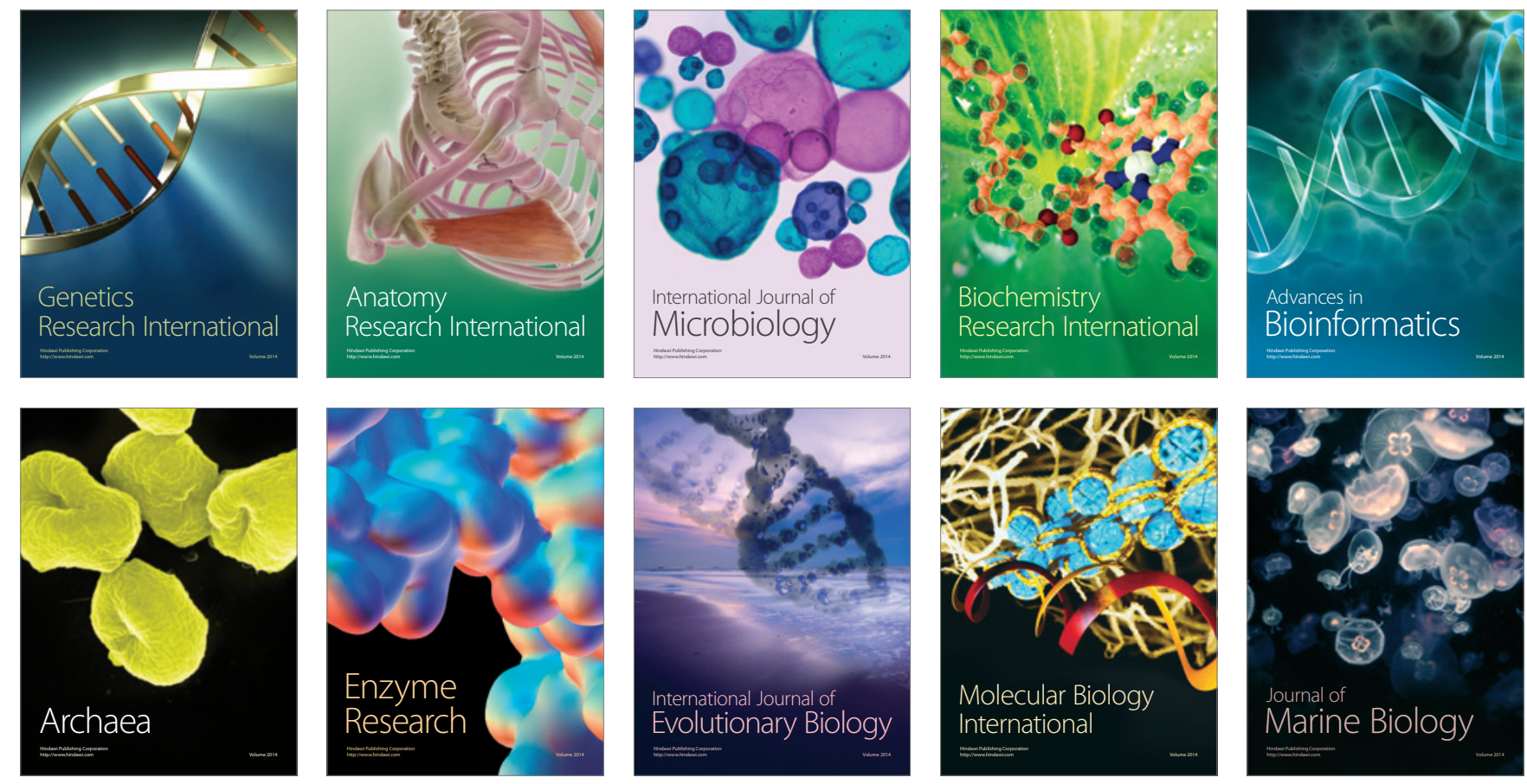